\title{
Population Dynamics of Spiders and Coccinellids in Rabi Tomato and Impact of Weather Parameters
}

\author{
Madhu E Hirur ${ }^{1 *}$, G. Anitha ${ }^{1}$, D. Anitha Kumari ${ }^{3}$ and G. Uma Devi ${ }^{2}$ \\ ${ }^{1}$ Department of Entomology, ${ }^{2}$ Department of Plant Pathology, \\ College of Agriculture, Rajendranagar, Hyderabad 500030, India \\ ${ }^{3}$ Vegetable Research Station, Sklts Horticultural University, \\ Rajendranagar, Hyderabad 500030, India \\ *Corresponding author
}

\section{A B S T R A C T}

\section{Keywords \\ Population \\ dynamics, Spiders, \\ Coccinellids, \\ Tomato, Weather parameters}

\section{Article Info}

Accepted:

07 August 2020

Available Online:

10 September 2020
Predators are important links in the food chain and are needed to maintain herbivore population in crop ecosystem in check. However, like other insects, they are also vulnerable to various weather factors, which impedes the natural control that they contribute to the ecosystem. Information on impact of weather factors on predators helps to understand natural control better and also formulate integrated pest management practices. The present study was conducted in the fields of Agricultural Research Institute, Rajendranagar during rabi 2018-19 with a view to study the population dynamics of various spiders and Coccinellids in tomato crop and the impact of weather factors on them. Results revealed that out of all the ten families of spiders recorded, Araneid spiders were the most abundantly found spiders in the crop (2.96 spiders/ quadrat), while Pholcids were the least commonly recorded (0.01 spiders/quadrat). Araneids, Oxyopids and Tetragnathids and the three Coccinellid genera were recorded from the first week after transplantation (43 SMW) to the end of the harvest (4 SMW), while the other species were recorded from the second week after transplantation to harvest. Spiders of family Theridiidae were recorded only in the last three weeks of the crop. Most of the weather factors except maximum temperature were found to have negligible impact on most of the spider species and Coccienllids.

\section{Introduction}

Pesticide usage is an effective and a common measure to counter pest problems in most crops. However, negative social and environmental consequences of chemicalintensive agriculture result in imbalance in agroecosystem have been observed since a long time. There is increased concern over risk of human health due to their excessive usage. However, natural control of insects and diseases is likely to reduce environmental disruption and human health risks compared to chemical pest control. For many pest species, natural enemies are the primary regulating force in the dynamics of their populations (Pedigo and Rice, 2009). Predators are widely used as biocontrol agents 
for regulating populations of pests (Lu et al., 2012) as well as important alternative to chemical (Desneux et al., 2011). Spiders and Coccinellids play an important role in regulating pests in agro-ecosystems in a very effective way. Spiders are ubiquitous in terrestrial agro-ecosystem, are generalist predators and considered more efficient than the specialist predators to suppress pest habitat (Memah et al., 2014). Characteristics which make them effective biological control agents are 1) the prey is killed rapidly 2) all individuals in the population (males and females, immature and adults) search for prey 3) Synchronisation in predator/prey life cycle is not a problem as they feed on detrivores and Collembolans in the absence of the pests (Anitha, 2016). The family Coccinellidae comprises of 330 genera and 4,500 species worldwide (Booth et al, 1990). Natural control by Coccinellids also is promising because of the predaceous habit of both adult and grub stages. Since, literature on the population dynamics of spiders and Coccinellids in tomato crop is scant, the present study focused these aspects of the useful predators.

\section{Materials and Methods}

The experiment was laid out in a plot of 500 sq.m. in Agricultural Research Institute (ARI), Rajendranagar during rabi 2018-19. The whole plot was divided into two blocks for study on spiders under sprayed and unsprayed situations with isolation distance of $750 \mathrm{~m}^{2}$ between them. Transplantation was done in October 2018 followed by a light irrigation at a spacing of $45 \times 15 \mathrm{~cm}$. The crop was grown with the recommended package of practices in all aspects but for spray of insecticides. One spray of Dimethoate 30 EC at the rate of $2 \mathrm{ml} / \mathrm{L}$ water was carried out in $49^{\text {th }}$ SMW. Population of spiders was counted in five quadrats each of the one sq $\mathrm{m}$. size in sprayed and unsprayed plots of tomato at weekly intervals from one week after transplanting till harvest. Application of pesticides as per recommendations was taken up in one plot, while the other was left unsprayed.

Spider and Coccinellid counts were taken by visual search method by the quadrat method once weekly from 7.00 am to $9.00 \mathrm{am}$. Unknown spider specimens were collected into glass vials, preserved in $70 \%$ alcohol and were sent to Dr. P. A. Sebastian Head, Division of Arachnology, Department of Zoology, Sacred Heart College, Thevara, Cochin-13, Kerala for identification. Coccinellids were identified by Dr K. Chitra Shankar, Prinicipal Scientist (Entomology), Indian Institute of Rice Research, Rajendranagar, Hyderabad.

Weekly observations on predators were correlated with weather parameters viz., maximum and minimum temperature, morning and evening relative humidity, rainfall and sunshine hours to understand their impact on population density of the predators. The value of Pearson correlation coefficient ' $r$ ' was calculated and it was compared with the ' $t$ ' probability value for ' $n$ ' number of observations to know the significance of the correlation. If it was found to be significant, the impact of different weather parameters on each of predator species was considered significant.

\section{Results and Discussion}

In the present study, 815 spiders belonging to ten families were observed. A total of 15 genera and 18 species were recorded. Araneidae, Lycosidae, Oxyopidae, Tetragnathidae, Salticidae, Thomisidae, Clubionidae, Linyphidae, Pholcidae and Theridiidae were recorded. Araneidae, Oxyopidae and Theridiidae recorded three species under them. While Araneidae was 
represented by Neoscona molemensis Tikader and Bal, 1981 Araneus mitificus (Simon, 1886) and Araneus sp, Oxyopidae had Peucetia viridana (Stoliczka, 1869), Oxyopes javanus Thorell, 1887 and Oxyopes sp. Species of Coleosoma sp, Theridion sp. and Enoplognatha sp were recorded under Theridiidae. Lycosidae was characterized by Wadicos aquadrifera (Gravely, 1924) and Geolycosa sp. Clubiona sp, Curubis, Thomisus globosus, Nasoona crucifera and Pholcus sp were recorded (Table 1).

Araneids were observed early during the first week after transplantation (43 ${ }^{\text {rd }}$ SMW) (Fig. 1). In sprayed block, population ranged from 0.00-3.8 spiders/quadrat and they contributed to $40.74 \%$ of the total spider population and were the most abundant family recorded. Their population level increased gradually in the next successive weeks and reached a peak during the Ist SMW (3.8 adults spiders/quadrat) whereas in unsprayed block population ranged from 0.85.8spiders/quadrat and reached peak during the Ist SMW (5.8 spiders/quadrat). Later the population level decreased gradually. Mean population was 2.22 spiders/quadrat in sprayed block whereas in unsprayed block it was 2.95 spiders/quadrat (Table 1). Population of Wadicosa quadrifera and Geolycosa sp of Lycosidae in sprayed block ranged from 0.2-2.00 spiders/quadrat. It increased gradually after the initial weeks and reached a peak during $4^{\text {th }}$ SMW (2 spiders/ quadrat), whereas in unsprayed block population ranged from 0.4-1.6 spiders/quadrat and reached a peak during $4^{\text {th }}$ SMW (1.6 adults/block). Later on there was a gradual decrease. Mean population was 0.77 spiders/quadrat in sprayed block whereas in unsprayed block it was 0.87 spiders/quadrat. Lycosidae contributed $12.09 \%$ of the total spider population, this was the third largest family found to inhabit the tomato field. Peucetia viridana, Oxyopes javanus and
Oxyopes sp. of Oxyopidae were observed on the crop early during first week after transplantation ( $43^{\text {rd }}$ SMW). In sprayed block, population ranged from 0-1.00 spiders/quadrat. The population reached a peak during $46^{\text {th }}$ SMW (1spider/quadrat) whereas in unsprayed block population built up from 0.4 spiders/quadrat and reached a peak during $55^{\text {th }}$ SMW (2.8 spiders/quadrat). Later the population decreased gradually with a mean of 0.45 spiders/quadrat in sprayed block and 1.51 spiders/quadrat.in unsprayed block. Their population was $21.45 \%$ of the total spider population and they were the second largest family recorded. Only one Tetragnathid viz., Tetragnatha javana (Thorell, 1890) was recorded during the first week after transplantation (43 ${ }^{\text {rd }}$ SMW) In sprayed block, population ranged from 0.000.60 spiders/quadrat. Population reached a peak during the second SMW (0.60spiders/quadrat) whereas in unsprayed block population ranged from 0.2-0.6 spiders/quadrat, with a peak in fourth SMW (0.6 spiders/quadrat). Mean population was 0.13 spiders/quadrat in sprayed block whereas in unsprayed block it was 0.24 spiders/quadrat. Tetragnathid population was merely $3.34 \%$ of the total spider population in the field. Salticid Curubis sp was observed on the crop early during the second week after transplantation. In sprayed block, population ranged from $0.00-0.40$ spiders/quadrat. Population levels fluctuated in the next successive weeks and reached a peak during the first SMW (0.4 adults per blocks) whereas in unsprayed block population ranged from 0.00-0.40 spiders/quadrat and reached a peak during forty ninth and fifty first SMW (0.4 spiders per block). Later the numbers decreased gradually and mean population was 0.13 spiders/quadrat in sprayed block whereas in unsprayed block it was 0.22 spiders/quadrat. They made up to only $3.34 \%$ of the total spider population in the field. 
Table.1 Population dynamics of spiders in rabi tomato

\begin{tabular}{|c|c|c|c|c|c|c|c|c|c|c|c|c|c|c|c|}
\hline \multirow{2}{*}{$\begin{array}{l}\text { Name of the } \\
\text { spider family }\end{array}$} & \multicolumn{15}{|c|}{ Population of Spiders (mean of five quadrats) } \\
\hline & $\begin{array}{l}\text { SMW } \\
43\end{array}$ & $\begin{array}{l}\text { SMW } \\
44\end{array}$ & $\begin{array}{l}\text { SMW } \\
45\end{array}$ & $\begin{array}{l}\text { SMW } \\
46\end{array}$ & $\begin{array}{l}\text { SMW } \\
\mathbf{4 7}\end{array}$ & $\begin{array}{l}\text { SMW } \\
48\end{array}$ & $\begin{array}{l}\text { SMW } \\
49\end{array}$ & $\begin{array}{l}\text { SMW } \\
\mathbf{5 0}\end{array}$ & $\begin{array}{l}\text { SMW } \\
51\end{array}$ & $\begin{array}{l}\text { SMW } \\
52\end{array}$ & $\begin{array}{l}\text { SMW } \\
1\end{array}$ & $\begin{array}{l}\text { SMW } \\
2\end{array}$ & $\begin{array}{l}\text { SMW } \\
\mathbf{3}\end{array}$ & $\begin{array}{l}\text { SMW } \\
4\end{array}$ & Mean \\
\hline Araneidae & 0.80 & 1.20 & 2.40 & 2.60 & 2.40 & 2.40 & 2.80 & 3.00 & 4.20 & 4.20 & 5.80 & 4.00 & 3.40 & 2.20 & 2.96 \\
\hline Lycosidae & 0.40 & 0.40 & 0.60 & 0.40 & 0.60 & 0.60 & 1.40 & 1.20 & 0.80 & 1.00 & 0.80 & 1.20 & 1.20 & 1.60 & 0.87 \\
\hline Oxyopidae & 0.40 & 0.60 & 0.80 & 0.80 & 0.60 & 1.00 & 2.60 & 2.80 & 2.40 & 2.40 & 2.60 & 2.20 & 1.40 & 0.60 & 1.51 \\
\hline Tetragnathidae & 0.20 & 0.20 & 0.20 & 0.40 & 0.20 & 0.20 & 0.40 & 0.20 & 0.20 & 0.00 & 0.00 & 0.20 & 0.40 & 0.60 & 0.24 \\
\hline Salticidae & 0.00 & 0.20 & 0.20 & 0.20 & 0.20 & 0.20 & 0.40 & 0.20 & 0.40 & 0.20 & 0.40 & 0.20 & 0.20 & 0.20 & 0.23 \\
\hline Thomisidae & 0.00 & 0.20 & 0.40 & 0.60 & 0.20 & 0.40 & 0.80 & 0.80 & 0.80 & 1.00 & 0.60 & 1.00 & 0.80 & 0.40 & 0.57 \\
\hline Clubionidae & 0.00 & 0.00 & 0.60 & 0.40 & 0.20 & 0.40 & 0.20 & 0.40 & 0.40 & 0.40 & 0.00 & 0.20 & 0.20 & 0.40 & 0.27 \\
\hline Linyphiidae & 0.00 & 0.20 & 0.40 & 0.60 & 0.60 & 0.40 & 0.40 & 0.80 & 0.60 & 0.80 & 0.40 & 0.40 & 2.00 & 0.40 & 0.57 \\
\hline Pholcidae & 0.00 & 0.20 & 0.00 & 0.00 & 0.00 & 0.00 & 0.00 & 0.00 & 0.00 & 0.00 & 0.00 & 0.00 & 0.00 & 0.00 & 0.01 \\
\hline Theridiidae & 0.00 & 0.00 & 0.00 & 0.00 & 0.00 & 0.00 & 0.00 & 0.00 & 0.00 & 0.00 & 0.00 & 0.20 & 0.20 & 0.40 & 0.06 \\
\hline
\end{tabular}

SMW-SMWs

Table.2 Population dynamics of Coccinellids

\begin{tabular}{|c|c|c|c|c|c|c|c|c|c|c|c|c|c|c|c|}
\hline $\begin{array}{l}\text { Name of the } \\
\text { genera }\end{array}$ & $\begin{array}{l}\text { SM } \\
\text { W } 43\end{array}$ & $\begin{array}{l}\text { SM } \\
\text { W } 44\end{array}$ & $\begin{array}{l}\text { SM } \\
\text { W } 45\end{array}$ & $\begin{array}{l}\text { SM } \\
\text { W } 46\end{array}$ & $\begin{array}{l}\text { SM } \\
\text { W } 47\end{array}$ & $\begin{array}{l}\text { SM } \\
\text { W } 48\end{array}$ & $\begin{array}{l}\text { SM } \\
\text { W } 49\end{array}$ & $\begin{array}{l}\text { SM } \\
\text { W } 50\end{array}$ & $\begin{array}{l}\text { SM } \\
\text { W } 51\end{array}$ & $\begin{array}{l}\text { SM } \\
\text { W } 52\end{array}$ & $\begin{array}{l}\text { SM } \\
\text { W } 1\end{array}$ & $\begin{array}{l}\text { SM } \\
\text { W } 2\end{array}$ & $\begin{array}{l}\text { SM } \\
\text { W } 3\end{array}$ & $\begin{array}{l}\text { SM } \\
\text { W } 4\end{array}$ & $\begin{array}{l}\text { Mea } \\
\text { n }\end{array}$ \\
\hline Scymnus sp & 0.80 & 0.80 & 1.00 & 0.80 & 1.00 & 1.00 & 0.80 & 0.60 & 0.60 & 0.60 & 0.40 & 0.60 & 0.60 & 0.60 & 0.73 \\
\hline Chelom & 60 & 0.80 & 080 & 0.80 & & & 1.00 & 0.60 & 0.60 & 0.40 & 0.40 & 0.20 & 0.20 & 0.20 & 0.60 \\
\hline Illeis sp & 0.80 & 0.60 & 0.40 & 0.40 & 0.40 & 1.20 & 1.00 & 1.00 & 0.80 & 0.80 & 0.60 & 0.60 & 0.60 & 0.80 & 0.71 \\
\hline
\end{tabular}


Table.3 Impact of weather parameters on spiders of different families

\begin{tabular}{|c|c|c|c|c|c|c|c|c|c|}
\hline S. No. & $\begin{array}{l}\text { Name of the } \\
\text { family }\end{array}$ & $\begin{array}{c}\text { Max. } \\
\text { Temperature }\end{array}$ & $\begin{array}{c}\text { Min. } \\
\text { Temperature }\end{array}$ & $\begin{array}{c}\text { Morning } \\
\text { Rel.humidity } \\
(\%)\end{array}$ & $\begin{array}{c}\text { Evening } \\
\text { Rel.humidity } \\
(\%)\end{array}$ & $\begin{array}{l}\text { Rainfall } \\
\text { (mm) }\end{array}$ & $\begin{array}{l}\text { Rainy } \\
\text { days }\end{array}$ & $\begin{array}{l}\text { Sunshine } \\
\text { (hrs) }\end{array}$ & $\begin{array}{c}\text { Wind } \\
\text { speed } \\
(\mathbf{k m} / \mathbf{h r})\end{array}$ \\
\hline 1 & Araneidae & $-0.66^{*}$ & -0.49 & 0.23 & 0.02 & -0.39 & -0.38 & -0.12 & -0.16 \\
\hline 2 & Lycosidae & $-0.59 *$ & $-0.69 *$ & 0.33 & 0.15 & -0.35 & -0.35 & 0.07 & -0.51 \\
\hline 3 & Oxyopidae & $-0.71 *$ & -0.29 & 0.29 & 0.32 & -0.26 & -0.25 & -0.36 & -0.09 \\
\hline 4 & Tetragnathidae & 0.32 & -0.27 & 0.08 & -0.22 & -0.12 & -0.10 & 0.41 & -0.47 \\
\hline 5 & Salticidae & -0.31 & -0.32 & -0.05 & -0.09 & -0.50 & -0.45 & -0.03 & -0.16 \\
\hline 6 & Thomisidae & $-0.78 *$ & -0.52 & 0.38 & 0.22 & -0.45 & -0.44 & -0.20 & -0.13 \\
\hline 7 & Clubionidae & -0.27 & 0.12 & 0.10 & 0.45 & -0.36 & -0.34 & -0.25 & 0.48 \\
\hline 8 & Linyphiidae & -0.32 & -0.35 & 0.45 & 0.09 & -0.34 & -0.34 & -0.03 & -0.21 \\
\hline 9 & Pholcidae & 0.32 & 0.19 & -0.12 & -0.29 & -0.10 & -0.10 & -0.01 & 0.05 \\
\hline 10 & Theridiidae & -0.18 & $-0.66^{*}$ & 0.26 & -0.24 & -0.17 & -0.17 & 0.34 & $-0.61 *$ \\
\hline
\end{tabular}

* Significant at $5 \%$ level

Table.4 Impact of weather parameters on Coccinellid genera

\begin{tabular}{|c|l|c|c|c|c|c|c|c|c|}
\hline S. No. Name of genera & $\begin{array}{c}\text { Max. } \\
\text { Temperature }\end{array}$ & $\begin{array}{c}\text { Min. } \\
\text { Temperature }\end{array}$ & $\begin{array}{c}\text { Morning } \\
\text { Rel.Humidity }(\boldsymbol{\%})\end{array}$ & $\begin{array}{c}\text { Evening } \\
\text { Rel.Humidity (\%) }\end{array}$ & $\begin{array}{c}\text { Rainfall } \\
(\mathbf{m m})\end{array}$ & $\begin{array}{c}\text { Rainydays } \\
\text { Sunshine } \\
(\mathbf{h r s})\end{array}$ & $\begin{array}{c}\text { Windspeed } \\
(\mathbf{k m} / \mathbf{h r})\end{array}$ \\
\hline $\mathbf{1}$ & Scymnussp & $0.58^{*}$ & 0.44 & $-0.59^{*}$ & -0.11 & 0.04 & 0.04 & 0.23 \\
\hline $\mathbf{2}$ & Cheilomenessp & $0.54^{*}$ & $0.56^{*}$ & $-0.62^{*}$ & -0.04 & -0.00 & $-1.10^{*}$ & 0.05 \\
\hline $\mathbf{3}$ & Illeissp & -0.25 & 0.15 & 0.38 & 0.51 & 0.13 & 0.13 & -0.41 & 0.18 \\
\hline
\end{tabular}


Fig.1 Time of occurrence of spiders of different families on tomato crop

\begin{tabular}{|c|c|c|c|c|c|c|c|c|c|c|c|c|c|c|}
\hline \multirow[b]{2}{*}{$\begin{array}{l}\text { Name of the } \\
\text { family }\end{array}$} & \multicolumn{14}{|c|}{ Period of observation } \\
\hline & $\begin{array}{l}\text { SMW } \\
43\end{array}$ & $\begin{array}{l}\text { SMW } \\
44\end{array}$ & \begin{tabular}{|l} 
SMW \\
45
\end{tabular} & $\begin{array}{l}\text { SMW } \\
46\end{array}$ & $\begin{array}{l}\text { SMW } \\
47\end{array}$ & $\begin{array}{l}\text { SMW } \\
48\end{array}$ & $\begin{array}{l}\text { SMW } \\
49\end{array}$ & $\begin{array}{l}\text { SMW } \\
50\end{array}$ & $\begin{array}{l}\text { SMW } \\
51\end{array}$ & $\begin{array}{l}\text { SMW } \\
52\end{array}$ & $\begin{array}{l}\text { SMW } \\
1\end{array}$ & $\begin{array}{l}\text { SMW } \\
2\end{array}$ & \begin{tabular}{|l} 
SMW \\
3
\end{tabular} & $\begin{array}{l}\text { SMW } \\
4\end{array}$ \\
\hline \multicolumn{15}{|l|}{ Araneidae } \\
\hline \multicolumn{15}{|l|}{ Lycosidae } \\
\hline \multicolumn{15}{|l|}{ Oxyopidae } \\
\hline \multicolumn{15}{|l|}{ Tetragnathidae } \\
\hline \multicolumn{15}{|l|}{ Salticidae } \\
\hline \multicolumn{15}{|l|}{ Thomisidae } \\
\hline \multicolumn{15}{|l|}{ Clubionidae } \\
\hline \multicolumn{15}{|l|}{ Linyphiidae } \\
\hline \multicolumn{15}{|l|}{ Pholcidae } \\
\hline Theridiidae & & & & & & & & & & & & & & \\
\hline
\end{tabular}

SMW-Standard meteorological week

Fig.2 Time of occurrence of different genera of Coccinellids

\begin{tabular}{|c|c|c|c|c|c|c|c|c|c|c|c|c|c|c|}
\hline \multirow[b]{2}{*}{ Name of genera } & \multicolumn{14}{|c|}{ Period of observation } \\
\hline & \begin{tabular}{|l|} 
SM \\
W 43
\end{tabular} & $\begin{array}{l}\text { SM } \\
\text { W } 44\end{array}$ & $\begin{array}{l}\text { SM } \\
\text { W } 45\end{array}$ & $\begin{array}{l}\text { SM } \\
\text { W } 46\end{array}$ & $\begin{array}{l}\text { SM } \\
\text { W } 47\end{array}$ & $\begin{array}{l}\text { SM } \\
\text { W } 48\end{array}$ & $\begin{array}{l}\text { SM } \\
\text { W } 49\end{array}$ & \begin{tabular}{|l|} 
SM \\
W 50
\end{tabular} & \begin{tabular}{|l|} 
SM \\
W 51
\end{tabular} & $\begin{array}{l}\text { SM } \\
\text { W } 52\end{array}$ & $\begin{array}{l}\text { SM } \\
\text { W 1 }\end{array}$ & \begin{tabular}{|l|} 
SM \\
W 2
\end{tabular} & $\begin{array}{l}\text { SM } \\
\text { W 3 }\end{array}$ & \begin{tabular}{|l|} 
SM \\
W 4
\end{tabular} \\
\hline Scymnussp & & & & & & & & & & & & & & \\
\hline Cheilomenessp & & & & & & & & & & & & & & \\
\hline Illeissp & & & & & & & & & & & & & & \\
\hline
\end{tabular}

SMW-Standard meteorological week 
Thomisus lobosus of Thomisidae were observed on the crop early during second week after transplantation. In sprayed block, population ranged from 0.00-0.60 spiders/quadrat and it oscillated between 0 and 0.4 spiders/quadrat and reached a peak during the second SMW (0.6 spiders/quadrat) whereas in unsprayed block population ranged from 0.00-1.00 spiders/quadrat and reached a peak during fifty second SMW and in second SMW (1 adult/quadrat). Mean population was 0.18 spiders/quadrat in sprayed block whereas in unsprayed block it was 0.57 spiders/quadrat. They constituted to $8.07 \%$ of the overall spider numbers.

Only one genus viz., Clubiona sp. of Clubionidae was recorded early during the second week $\left(44^{\text {th }}\right.$ SMW) after transplantation. In sprayed block, population swing between $0.00-0.20$ spiders/quadrat whereas in unsprayed block population reached a peak from 0 to 0.6 spiders/quadrat. Mean population was 0.11 spiders/quadrat in sprayed block whereas in unsprayed block it was 0.27 spiders/quadrat. Clubionids made up to $3.74 \%$ of the entire spider population in the field. Nasoona crucifera of Linyphiidae, which were observed on the crop early during the $2^{\text {nd }}$ week after transplantation. In sprayed block, population ranged from 0.00-0.60 spiders/quadrat. Their population level increased gradually in the next successive weeks and reached a peak during the $2^{\text {nd }}$ and $3^{\text {rd }}$ SMW (0.6 adults/quadrat) whereas in unsprayed block population ranged from 0.00-2.00 spiders/quadrat and reached a peak during $3^{\text {rd }}$ SMW (2.0 spiders/quadrat) in unsprayed block. Mean population was 0.24 spiders/quadrat in sprayed block whereas in unsprayed block it was 0.57 spiders/quadrat. Linyphiids occupied $6.29 \%$ of the total spider population. Pholcussp of Pholcidae, were observed on the crop early in the season i.e. during $2^{\text {nd }}$ week after transplantation (SMW43). In both sprayed and unsprayed block population ranged from $0.00-0.20$ species per quadrat and they were not observed during later stages of crop growth. Mean population was 0.01 species per quadrat in sprayed block and unsprayed block. This family made up to merely $0.20 \%$ of the entire spider population.

Theridiidae was probably the only family with a large diversity of spider web forms. Coleosoma sp, Theridion sp and Enoplognatha sp .were observed during flowering and fruit formation stage. In sprayed block, population ranged from 0.00 0.20 species per quadrat whereas in unsprayed block 0.00-0.40 species per quadrat. Mean population was 0.028 species per quadrat in sprayed block whereas in unsprayed block it was 0.06 species per quadrat. Theridiids occupied only $0.79 \%$ of the entire spider number in the field.

\section{Population dynamics of Coccinellids}

In the present study, three species of Coccinellids viz., Scymnus sp, Cheilomenes sp and Illeis sp were found to inhabit the tomato ecosystem.

Scymnus were observed on the crop early during $\mathrm{I}^{\mathrm{st}}$ week after transplantation (Fig. 2). In the sprayed block, population ranged from $0.20-0.80$ beetles/quadrat (Table 2) and their populations increased slowly in the next successive weeks and reached a peak during $46^{\text {th }}$ standard week $(0.08$ beetles/quadrat $)$ whereas in unsprayed block population varied between 0.40-1.00 beetle per quadrat and reached a peak during $45^{\text {th }}, 47^{\text {th }}$ and $48^{\text {th }}$ standard weeks ( 1 beetle/quadrat). Later the population decreased gradually. Mean population was 0.46 beetles/quadrat in sprayed block whereas in unsprayed block it was 0.73 beetles/quadrat. Cheilomenes sp. were observed on the crop early during the Ist week after transplantation $\left(43^{\text {rd }}\right.$ standard week). In the sprayed block, population 
ranged from $0.20-0.40$ beetles/quadrat and their numbers decreased gradually in the next successive weeks registering 0.2 beetles/quadrat, whereas in unsprayed block population ranged from 0.20-1.00 beetles/quadrat and reached a peak during $49^{\text {th }}$ standard week (1 beetle/quadrat). Later their population decreased gradually. Mean population was 0.24 beetles/quadrat in sprayed block whereas in unsprayed block it was 0.6 beetles/quadrat. Illeis sp. were observed on the crop early during the first week after transplantation. In the sprayed block, population ranged from 0.20-0.80 beetles/quadrat with a peak during $45^{\text {th }}$ standard week ( 0.8 beetles/quadrat $)$ whereas in unsprayed block population ranged from 0.40-1.20 beetles/quadrat and reached a peak during $48^{\text {th }}$ standard week (1.2 beetles/quadrat). Later the population level decreased gradually towards the end of the season. Mean population was 0.43 beetles/quadrat in sprayed block whereas in unsprayed block it was 0.71 beetles/quadrat.

\section{Impact of weather parameters on spiders}

The effect of maximum temperature, minimum temperature, morning relative humidity, evening relative humidity, rainfall and sunshine hours on different genera of spiders during the crop period is discussed below.

Significant and negative impact of maximum temperature was observed on Araneids ( $\mathrm{r}=$ 0.664, $\mathrm{p}<0.05)$, Lycosids $(\mathrm{r}=-0.596, \mathrm{p}<0.05)$ and Oxyopids $(\mathrm{r}=-0.713, \mathrm{p}<0.05)$, and Thomisidae ( $\mathrm{r}=-0.781, \mathrm{p}<; 0.05)$. Lycosids were significantly impacted by minimum temperature $(\mathrm{r}=-0.693, \mathrm{p}<0.05)$ also in addition to maximum temperature. Theridiid spiders were found to be negatively and significantly associated with minimum temperature $(-0.66, \mathrm{p}<0.05)$ and wind speed $(0.61, \mathrm{p}<0.05)$, while all other parameters had a negligible impact on these spiders. Tetragnathids, Salticids, Pholcids, Linyphiidae and Clubionids were found to be unaffected by any of the weather parameters. Thus most of the spiders were found to be unaffected by the weather parameters, which ensures uninterrupted natural control in the crop ecosystem (Table 3). Contrary to our results, El-Khouly et al., (2014) concluded that temperature has a positive correlation whereas relative humidity showed negative correlation with population of spiders. The present study helps to understand the population levels of predators in the fields which would help us to formulate pest management techniques with least disruption to the beneficial insects.

\section{Impact of weather parameters on Coccinellids}

Scymnus sp were found to be positively and significantly correlated with maximum temperature $(\mathrm{r}=0.58, \mathrm{p}<0.05)$ and significantly and negatively correlated with relative humidity in the morning $(\mathrm{r}=-0.59, \mathrm{p}<0.05)$ (Table 4). All other parameters had no impact on Scymnus sp. Cheilomenes sp was found to be significantly and positively influenced by maximum temperature $(\mathrm{r}=0.54, \mathrm{p}<0.05)$ and minimum temperature $(\mathrm{r}=0.56, \mathrm{p}<0.05)$. Morning relative humidity $(\mathrm{r}=0.62, \mathrm{p}<0.05)$ and rainy days $(\mathrm{r}=-1.10, \mathrm{p}<0.05)$ were found to have significant negative impact. No weather parameter was found to have significant impact on Illeis sp. (Table 4).

\section{References}

Anitha, G. 2016. Abunance of spider and coccinellids predators and their impact analysis on major pests in varied rice system. Unpublished $\mathrm{PhD}$ thesis submitted to Professor Jayashakar Telangana State Agricultural University, Rajendranagar, Hyderabad, Telangana 
State. 1-229.

Booth, R.G., Cox, M.L. and Madge, R.B. 1990. IIE guides to insects of important to man. International institute of entomology., London.

Desneux, N., Luna, M.G., Gullemaud,T. and Urbaneja, A. 2011. The invasive south American tomato pinworm, Tutaabsoluta continues to spread in Afro-Eurasia and beyond: the new threat to tomato world production. Journal of Pest Science. 84: 403-408.

El-khouly, N.M., Rahil, A.A., and Dwedar, E.F. 2014. Survey of spiders populations (Araneae) in tomato fields at fayoum governorate. Pp. 1-24.

El-Tohamy, W.A., El-Abagy, H.M., Ahmed, E.M., Aggor, F.S. and Hawash, S.I. 2014.Application of super hydrogel poly (acrylate/acrylic acid) for water conservation in sandy soil. Transaction of the Egyptian Society of chemical engineering. 40(2): 1-8.

FAOSTAT.2008. http://faostat.fao.org/.aspx.

Lu, Y., Wu, K., Jiang, Y., Guo, Y. and Desneux, N. 2012. Widespread adoption of $\mathrm{Bt}$ cotton and insecticide decrease promotes bio-control services. Nature. 487: 362-365.

Memah, V.V., Tulung, M., Warouw, J. and Maramis, R.R.T.D. 2014. Diversity of spider species in some agricultural crops in North Sulawesi, Indonesia. International Journal of Scientific \& Engineering Research. 5: 70-75.

Pedigo, P.L. and Rice, M.E. 2009. Entomology and pest management. Person prentice Hall, 784 pp.

Uysal-Pala, C. and Bilisi, A. 2006. Fate of endosulfan and deltamethrin residues during tomato paste production. Journal of central European Agriculture. 7(2): 343-348.

\section{How to cite this article:}

Madhu E. Hirur, G. Anitha, D. Anitha Kumari and Uma Devi, G. 2020. Population Dynamics of Spiders and Coccinellids in Rabi Tomato and Impact of Weather Parameters. Int.J.Curr.Microbiol.App.Sci. 9(09): 562-570. doi: https://doi.org/10.20546/ijcmas.2020.909.071 